\title{
Childhood non-Hodgkin lymphomas in the United Kingdom: findings from the UK Children's Cancer Study Group
}

\author{
Dennis Wright, Patricia McKeever, Richard Carter
}

\begin{abstract}
Aim-To review the presenting clinical features and the histology of cases of nonHodgkin lymphoma (NHL) entered into the United Kingdom Children's Cancer Study Group NHL Trial.

Methods-Sections of biopsy specimens from all cases entered into the trial were stained with Giemsa and haematoxylin and eosin. All cases were stained immunohistochemically for CD45, CD3, CD45RO, CD20, and CD30. Sections were stained with either naphthol AS-D chloroacetate esterase or KP1 (CD68) to identify granulocytic tumours. In a minority of cases, additional immunohistochemical stains were performed when necessary to establish the diagnosis. The sections were reviewed by three pathologists.
\end{abstract}

Results-Of 308 cases analysed, 293 were categorised as NHL. There was only one case of low grade lymphoma in the series. Over $80 \%$ of the cases fell into the categories Burkitt lymphoma (42.2\%), lymphoblastic lymphoma $(27.2 \%)$ and anaplastic large cell lymphoma (15.1\%). Cases of Burkitt lymphoma presented most often with abdominal tumours mainly of the ileocaecal region. Tumours of the oropharynx and nasopharynx were also common in this group. Of the 84 lymphoblastic lymphomas, 56 were of the T-cell phenotype, 12 of the $B$-cell phenotype and 16 of indeterminate lineage. Most of the T-lymphoblastic lymphomas showed mediastinal or pleural involvement. Infiltration of the skin and soft tissues was seen in $25 \%$ of lymphoblastic lymphoma of $B$ or indeterminate phenotype. Forty six children were diagnosed as having anaplastic large cell lymphoma, the majority being of $T$ or indeterminate lineage. Most patients presented with lymphadenopathy but involvement of the bones, soft tissues or skin was seen in seven patients and of the mediastinum and lungs in five.

Conclusion-Childhood non-Hodgkin lymphomas are almost all high grade and frequently extranodal. They fall mainly into the categories Burkitt lymphoma, lymphoblastic lymphoma and anaplastic large cell lymphoma. The separation of these subcategories can be made on the basis of morphology and immunohistochemical features. The anatomical distribution of these different categories of non-Hodgkin lymphoma is distinctive.

( Clin Pathol 1997;50:128-134)

Keywords: childhood non-Hodgkin lymphoma; Burkitt lymphoma; lymphoblastic lymphoma; anaplastic large cell lymphoma.

Non-Hodgkin lymphomas represent $4-6 \%$ of all malignant neoplastic disease of childhood. ${ }^{1}$ About $85 \%$ of children in the United Kingdom with non-Hodgkin lymphomas are enrolled in the NHL trials organised by the United Kingdom Children's Cancer Study Group (UKCCSG), amounting to approximately 80 new cases each year. The original diagnostic biopsy specimens from these children were examined by a separate review panel and, in this report, the panel's findings are presented for nearly 300 cases. Paediatric non-Hodgkin lymphomas differ from the adult disease, in that they are almost all high grade, have a diffuse growth pattern and commonly involve extranodal sites. The majority of our cases fell into one of three diagnostic groups: Burkitt lymphoma, lymphoblastic lymphoma and anaplastic large cell lymphoma. Treatment regimes for these three categories differ, ' and as they are rapidly progressive tumours, optimum management requires both prompt and accurate histological diagnosis.

\section{Methods}

Ten unstained paraffin wax sections and a copy of the pathology report were requested for all patients entered into the UKCCSG NHL trials. In exceptional cases, a tissue block was submitted and occasionally the panel chairman obtained additional sections. Many of the biopsy specimens had already been referred to a paediatric pathologist at the treatment centre for review and the results of the investigations done at the referral laboratory were usually available. All sections were stained with haematoxylin and eosin and with Giemsa stain. Immunohistochemistry, using either the APAAP or the immunoperoxidase method, was performed routinely with $\mathrm{CD} 45$, the lineage markers CD3 and CD20, and with CD45RO (UCHL1) and CD30. In the early part of the study, one section was routinely stained for naphthol AS-D chloroacetate esterase to identify granulocytic tumours. This was later replaced by immunohistochemical staining for CD68 (KP1). Sections in individual cases were also stained with antibodies directed against 
Table 1 UKCCSG NHL trials: overall summary of panel diagnoses and sex distribution of the cases

\begin{tabular}{|c|c|c|c|}
\hline Diagnosis & Number (\%) & Male & Female \\
\hline Burkitt lymphoma & $130(42.2)$ & 110 & 20 \\
\hline $\begin{array}{l}\text { Lymphoblastic } \\
\text { T } 56 \text {; indeterminate } 16 \text {; B } 12\end{array}$ & $84(27.2)$ & 57 & 27 \\
\hline $\begin{array}{l}\text { Large cell anaplastic } \\
\quad \text { Indeterminate } 22 ; \mathrm{T} 16 ; \text { ? } 6 \text {; B2 }\end{array}$ & $46(15.0)$ & 29 & 17 \\
\hline Centroblastic/Centroblastic centrocytic & $10(3.3)$ & 6 & 4 \\
\hline $\begin{array}{l}\text { Other B-lineage lymphomas } \\
\text { B-high grade (NOS) } 12^{\mathrm{a}} \text {; primary mediastinal } \\
\text { large B-cell lymphoma 1; T-cell-rich B-cell } \\
\text { lymphoma } 1\end{array}$ & $14(4.5)$ & 9 & 5 \\
\hline $\begin{array}{l}\text { Other T-lineage lymphomas } \\
\text { Peripheral T3; T-high-grade (NOS) } 1^{\mathrm{b}}\end{array}$ & $4(1.3)$ & 2 & 2 \\
\hline Histiocytic & $1(0.3)$ & - & 1 \\
\hline Non-Hodgkin lymphoma (NOS) ${ }^{c}$ & $4(1.3)$ & 2 & 2 \\
\hline $\begin{array}{l}\text { Reactive/no evidence of lymphoma/inadequate } \\
\text { material }\end{array}$ & $11(3.6)$ & 6 & 5 \\
\hline No diagnosis made & $4(1.3)$ & 3 & 1 \\
\hline Total & $308(100)$ & 224 & 84 \\
\hline
\end{tabular}

${ }^{a}$ Ten of the 12 cases incompletely classified because of poor quality material.

${ }^{b}$ Incompletely classified because of poor quality material.

'Two of the four cases incompletely classified because of poor quality material.

epithelial membrane antigen (EMA), S-100 and, in a few instances, with antibodies

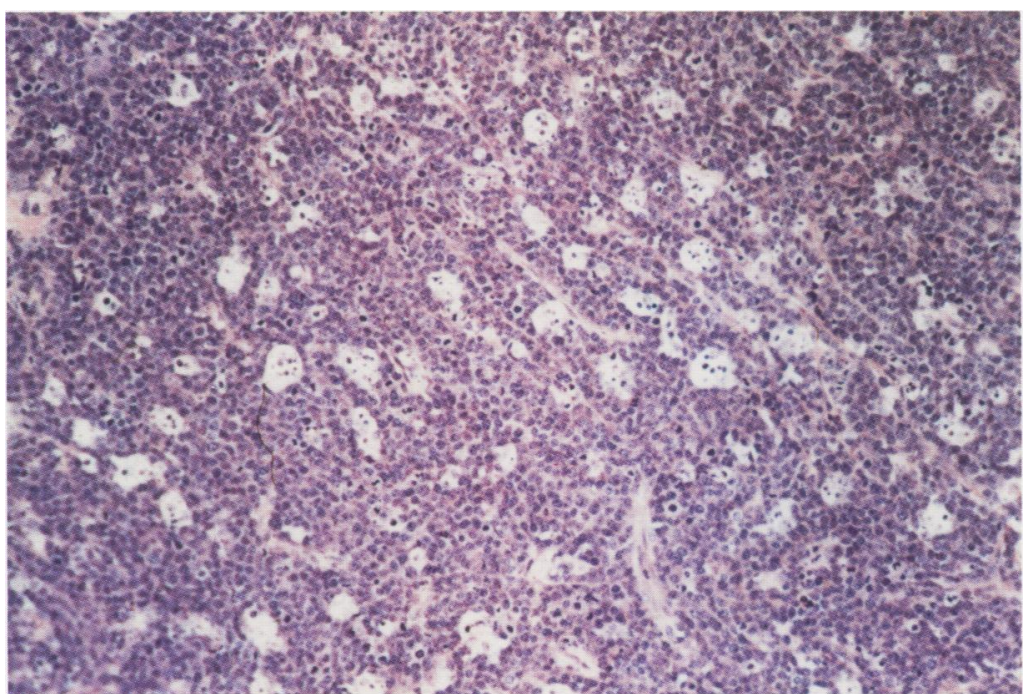

Figure 1 Low power view of Burkitt lymphoma showing sheets of monomorphic lymphoid cells interspersed with large, clear macrophages containing apoptotic debris, giving the characteristic starry sky pattern (original magnification $\times 80$ ).

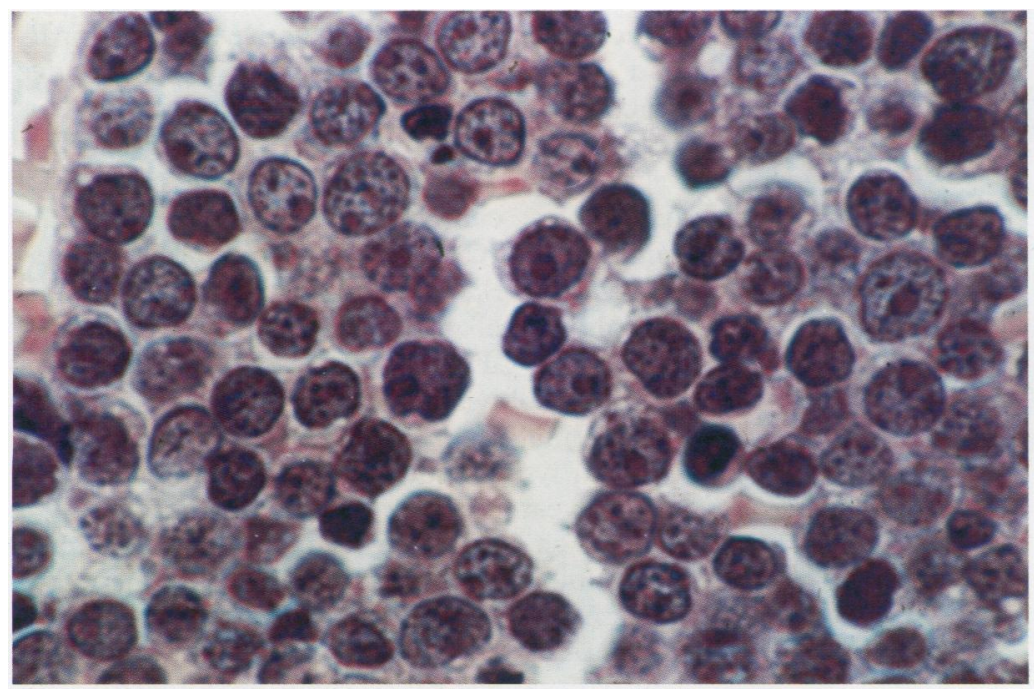

Figure 2 Burkitt lymphoma showing monomorphic blast cells with granular nuclear chromatin and one or more, usually inconspicuous, nucleoli. The cytoplasm of these cells is well-defined, amphophylic and contains small, lipid vacuoles (original magnification $\times 800$ ). directed against muramidase, bcl-2 and the $\mathrm{Ki}-67$ antigen.

The sections were then circulated among the three members of the review panel who categorised them independently using the Kiel classification. The panel came together, on a few occasions, to review those cases in which there was disagreement and to reach a consensus opinion.

\section{Results}

Of 308 cases analysed by the panel, 293 were categorised as non-Hodgkin lymphoma (table 1). In 11 cases, the sections were considered to be inadequate for diagnosis or to show no evidence of lymphoma. No diagnosis was made in four cases. There was only one case of low grade lymphoma in the series. This was a follicle centre cell lymphoma, centroblastic/ centrocytic follicular, presenting as lymphadenopathy in a 14 year old boy. Two cases of centroblastic lymphoma, follicular and diffuse, and seven cases categorised as centroblastic, diffuse would fall into the intermediate grade of the Working Formulation. Twelve biopsy specimens designated B-cell, high grade NOS, because the quality of the histological preparations did not permit a more exact diagnosis, were probably Burkitt lymphomas. Almost $90 \%$ of the cases, therefore, fell within the categories of Burkitt lymphoma, lymphoblastic lymphoma and anaplastic large cell lymphoma.

\section{BURKITT LYMPHOMAS}

Burkitt lymphomas showed a monomorphic proliferation of blast cells with rounded nuclei and granular nuclear chromatin. The cells contained one to four nucleoli which were identifiable but rarely prominent. Tumours always showed a high mitotic index and large numbers of apoptotic cells and nuclear fragments. The latter were often engulfed by macrophages that gave the tumour a characteristic starry sky appearance (fig 1). Burkitt lymphoma cells had a well-defined, but narrow, rim of deeply basophilic cytoplasm, best seen in Giemsa stained sections and usually best visualised at the edge of the section (fig 2). Small vacuoles corresponding to lipid droplets were seen within this rim of cytoplasm in many cases (fig 2). The tumour cells were positive for CD45 and CD20 and negative for T-lineage markers and CD 30.

LYMPHOBLASTIC LYMPHOMAS

Lymphoblastic lymphomas also showed a monomorphic proliferation of blast cells with round, oval or convoluted nuclear outlines. The nuclear chromatin was fine and dispersed with two to four small nucleoli. Tumours showed a high mitotic index with frequent apoptotic cells. A starry sky pattern with vacuolated macrophages was occasionally seen but was rarely as prominent as in Burkitt lymphoma (fig 3 ). The cytoplasm of these cells was inconspicuous and showed weak to moderate basophilia in the Giemsa stain in contrast to Burkitt lymphoma cells (fig 4). Most lymphoblastic lymphomas were positive for CD45 but 13 examples did not stain; nine 


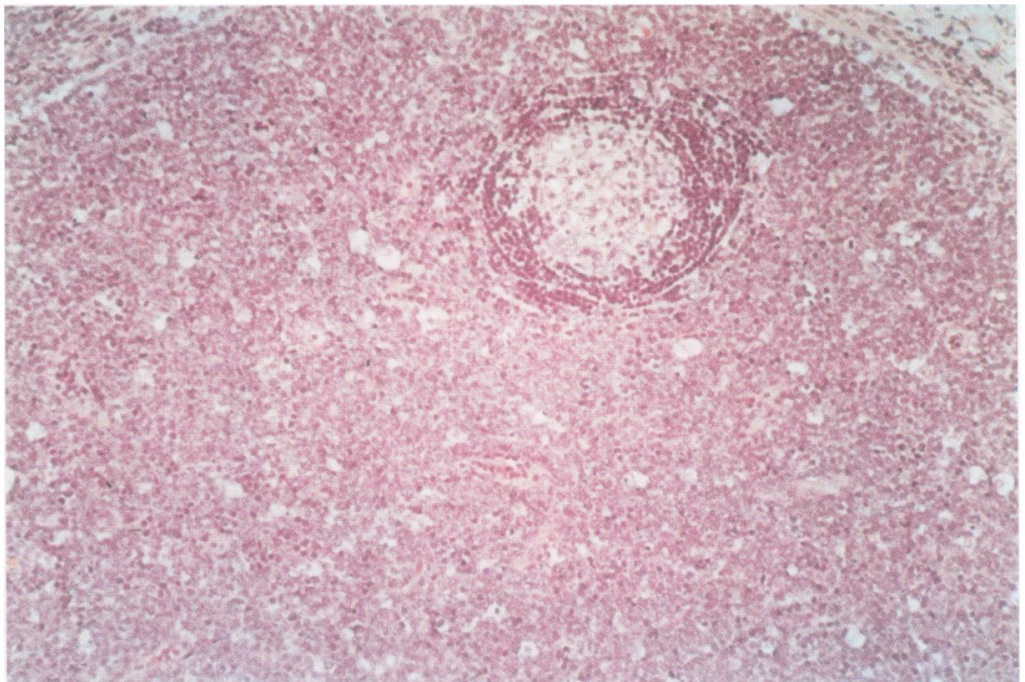

Figure 3 Lymphoblastic lymphoma showing a diffuse infiltrate of blast cells replacing most of the lymph node structure, apart from one residual germinal centre. There are scattered clear histiocytes, giving a starry sky pattern less noticeable than that seen in Burkitt lymphoma (original magnification $\times 80$ ).

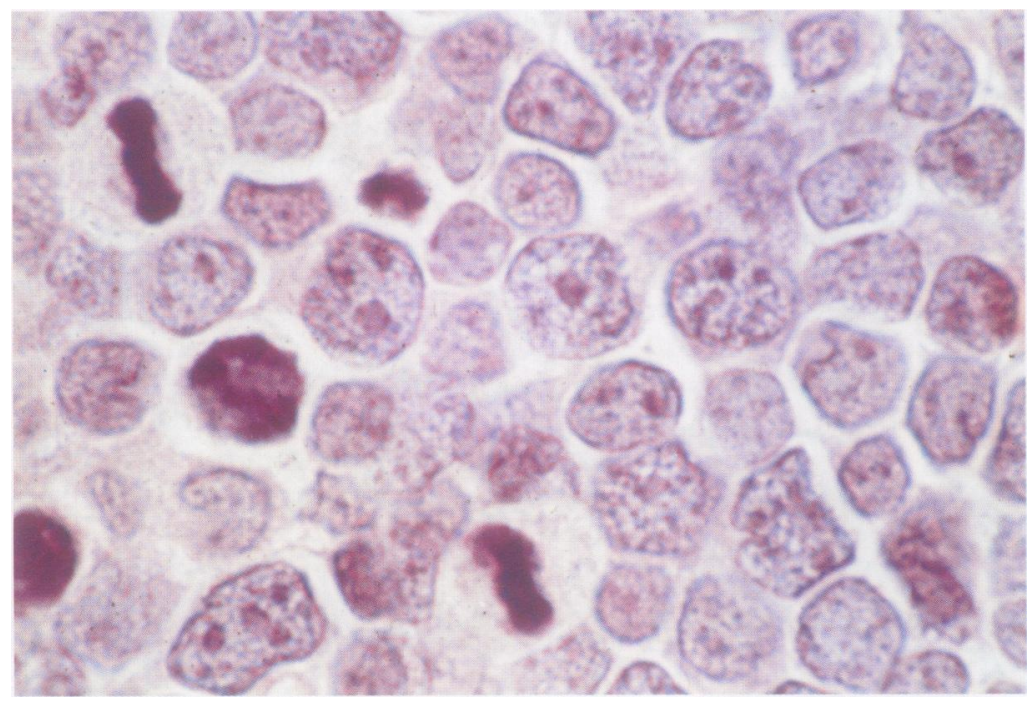

Figure 4 Lymphoblastic lymphoma showing blast cells with fine nuclear chromatin and one or more nucleoli. Mitotic figures are frequent. The cytoplasm is ill-defined and pale staining (original magnification $\times 800$ ).

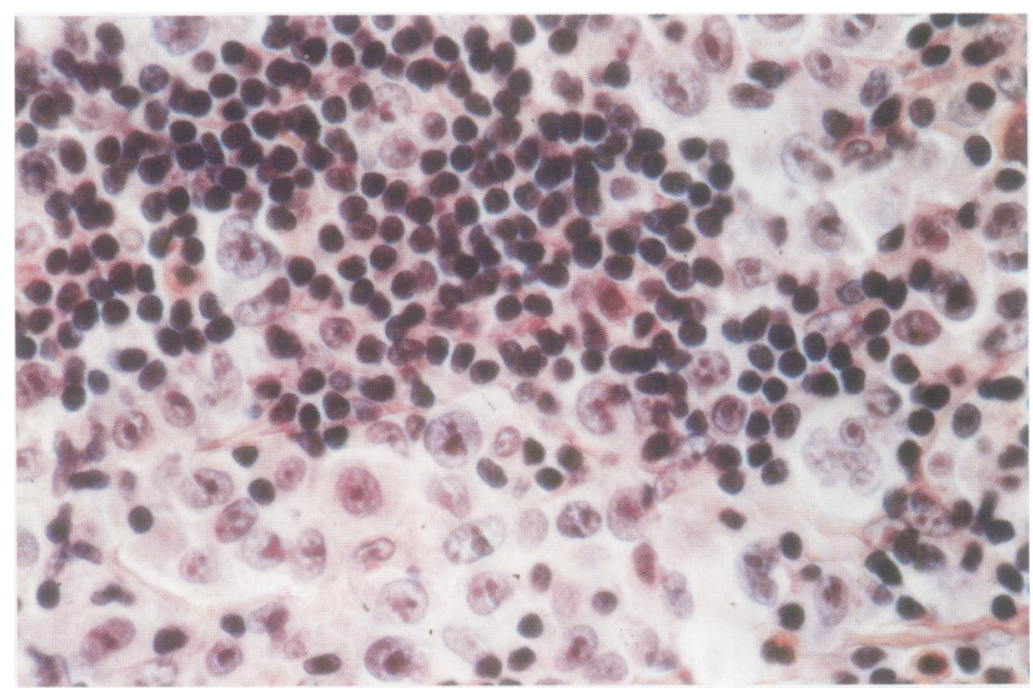

Figure 5 Anaplastic large cell lymphoma. In this tumour, the neoplastic cells have regular, oval nuclei, usually with a single nucleolus. The cytoplasm of these cell is abundant and eosinophilic (original magnification $\times 320$ ).

of these were of T-lineage. T-lymphoblastic lymphomas were identified by the expression of
CD3, and B-lineage tumours by the expression of CD20. Tumours expressing neither CD3 nor CD20 were categorised as being of indeterminate lineage.

\section{ANAPLASTIC LARGE CELL LYMPHOMA}

Anaplastic large cell lymphomas were composed of large cells with pleomorphic, horseshoe shaped (embryo-like) nuclei. In some instances, multiple nuclei occurred in a wreathlike pattern and sometimes gave rise to cells resembling Reed-Sternberg cells (although in no instance did the panel have difficulty in separating anaplastic large cell lymphoma from Hodgkin disease). Tumour cells with more monomorphic rounded nuclei also frequently occurred, either as the predominant population or mixed with the more pleomorphic variants (fig 5). Anaplastic large cell lymphoma cells had more abundant cytoplasm than other lymphomas, although the staining quality of this cytoplasm was variable. In biopsy specimens where the lymph node architecture was partially retained, the tumour cells characteristically grew within the sinuses. In a few cases, they showed a very notable perivascular distribution. In some examples, the tumour was accompanied by an intense infiltrate of inflammatory cells which, on occasions, masked the neoplastic cells. All cases diagnosed as anaplastic large cell lymphoma showed expression of CD30 (BERH2) on the tumour cell membrane and in the Golgi region (fig 6). It highlighted the tumour cells and frequently accentuated their cohesive nature. Expression of CD45 was variable, with no staining observed in 18 cases. Cases in which the tumour cells expressed CD3 were categorised as being of the T-cell phenotype. In two cases, the tumour cells expressed CD20 in the absence of T-lineage markers and were classified as being of the B-cell lineage. Cases not expressing CD3 or CD20 were categorised as being of indeterminate lineage. In 22 biopsy specimens, the tumour cells expressed EMA, although staining was sometimes weak, focal, and present in only a few of the neoplastic cells.

A single case was diagnosed as a histiocytic sarcoma on the basis of negative staining for Band $\mathrm{T}$-cell lineage markers with positive reactivity for CD68 and muramidase. This tumour occurred as a pelvic mass in a three year old girl. The case of follicle centre cell lymphoma, centroblastic/centrocytic and the nine cases of centroblastic lymphoma (follicular or diffuse) were diagnosed using standard morphological criteria; all of them expressed CD45 and CD20. A mediastinal tumour from a 15 year old girl was diagnosed as a primary mediastinal (thymic) large B-cell lymphoma. A cervical lymph node biopsy specimen from a seven year old boy was diagnosed as a T-cell-rich B-cell lymphoma, on the basis of its morphology and phenotype. Four biopsy specimens were categorised as peripheral T-cell lymphomas, as distinct from anaplastic large cell lymphoma. All of them were negative for CD30.

The main anatomical sites of disease for the three major groups of childhood non-Hodgkin 


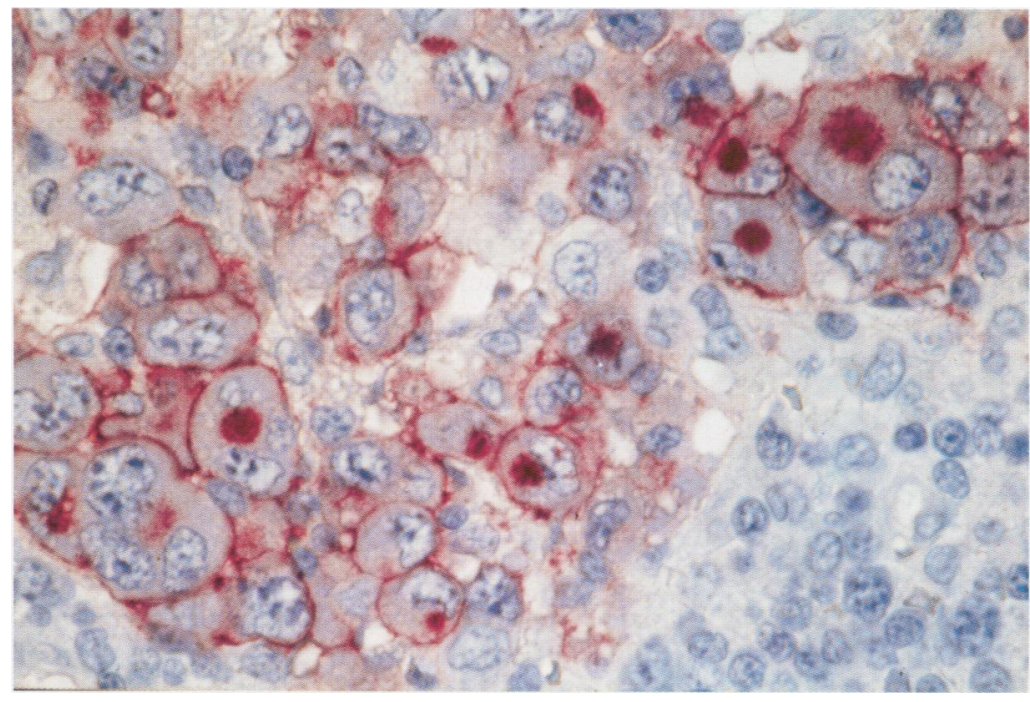

Figure 6 Anaplastic large cell lymphoma stained to show CD30. Note the strong membrane and Golgi staining. Many of the tumour cells in this neoplasm have irregular nuclei or appear multinucleated (APAAP; original magnification $\times 320)$.

lymphomas are shown in table 2 . One hundred and thirty $(42.2 \%)$ cases were categorised as Burkitt lymphoma (table 1). Eighty eight of these 130 patients presented with abdominal tumours. These were often extensive and their exact location was not recorded. In 37 cases, the tumour was noted to involve the terminal ileum or ileocaecal region. Three tumours involved the stomach and four were localised to the ovaries. Seventeen patients presented with tumours in Waldeyer's ring. Nine of these involved the oropharynx or tonsil and eight the nasopharynx. Only 13 of the 130 patients presented with peripheral lymphadenopathy. Twelve cases designated high grade, B-cell lymphoma, NOS were probably poorly preserved Burkitt lymphomas with a similar anatomical distribution to the cases diagnosed as Burkitt lymphoma. With the addition of these cases, Burkitt lymphoma would constitute $46 \%$ of the whole series.
Eighty four $(27.2 \%)$ cases were diagnosed as lymphoblastic lymphoma. Of these, 56 were T-cell, 12 B-cell and 16 of indeterminate lineage. Thirty two (38\% of the whole series) presented with peripheral lymphadenopathy. Infiltration of the skin and soft tissues was observed in $25 \%$ of patients with lymphoblastic lymphomas of $\mathrm{B}$ and indeterminate lineages. Twenty seven (32\%) of the 56 T-lymphoblastic lymphomas showed involvement of the mediastinum or pleura, a localisation not seen in lymphoblastic lymphomas of B-cell or indeterminate subtypes.

Forty six $(15 \%)$ cases were diagnosed as anaplastic large cell lymphoma. About $70 \%$ presented with peripheral lymphadenopathy, but several other sites were also involved. Seven patients presented with lymphoma in bones, soft tissue or skin, and five with disease in the mediastinum or lungs.

In the whole series, there were 224 males and 84 females, giving a male to female sex ratio of 2.7:1 (table 3). The male to female sex ratio of Burkitt lymphoma was 5.5:1, whereas for lymphoblastic lymphomas it was 2.1:1 and for anaplastic large cell lymphoma 1.5:1. Of the 293 cases, 288 fell within the age range of one to 15 years (table 3 ). There was only one patient under the age of one year and four over the age of 16 , although the small number of patients in the latter category was due to the selection criteria for the trial. The patients seem to be roughly equally spread over the age range from one to 15 years, although Burkitt lymphoma is slightly more common in the middle, lymphoblastic lymphoma in the first, and anaplastic large cell lymphoma in the last quinquennium.

After an initial settling in period, the review panel achieved a concordance rate of over $90 \%$ on first review. This is, perhaps, not surprising, as $90 \%$ of the patients fell within three categories that differed, not only in their morphology

Table 2 UKCCSG NHL trials: principal anatomical sites of disease for the three major histological subtypes

\begin{tabular}{|c|c|c|c|c|c|}
\hline \multirow[b]{2}{*}{ Anatomical site } & \multirow[b]{2}{*}{$\begin{array}{l}\text { Burkitt lymphoma } \\
(n=130)\end{array}$} & \multicolumn{3}{|c|}{ Lymphoblastic } & \multirow[b]{2}{*}{$\begin{array}{l}\text { Anaplastic large cell } \\
(n=46)\end{array}$} \\
\hline & & $T(n=56)$ & $\begin{array}{l}\text { Indeterminate } \\
(n=16)\end{array}$ & $B(n=12)$ & \\
\hline Peripheral lymph nodes & 13 & 21 & 5 & 6 & 32 \\
\hline Abdominal/pelvic mass ${ }^{a}$ & 40 & - & 1 & - & - \\
\hline Ileum, ileocaecal region & 37 & - & - & - & - \\
\hline Mediastinum, pleura $^{\mathrm{b}}$ & - & 27 & - & - & 3 \\
\hline Oropharynx, tonsil & 9 & 1 & - & 1 & - \\
\hline Skin, soft tissue & - & 3 & 4 & 3 & 5 \\
\hline Bone & 7 & 1 & - & - & 2 \\
\hline Nasopharynx, nasal cavity & 8 & 1 & - & - & - \\
\hline Salivary glands & 2 & 1 & 2 & - & 1 \\
\hline Brainc & 1 & 1 & 2 & - & - \\
\hline Bone marrow & 2 & - & 1 & 2 & - \\
\hline Liver & 3 & - & - & - & - \\
\hline Testis & - & 2 & 1 & 1 & - \\
\hline Ovary $^{d}$ & 4 & - & - & - & - \\
\hline Stomach & 3 & - & - & - & - \\
\hline Duodenum, pancreas & 1 & - & - & - & 1 \\
\hline Lungs & - & - & - & - & 2 \\
\hline Oral cavitye & - & - & - & - & - \\
\hline Total & 130 & $56(+2)^{f}$ & 16 & $12(+2)^{\mathrm{g}}$ & 46 \\
\hline
\end{tabular}

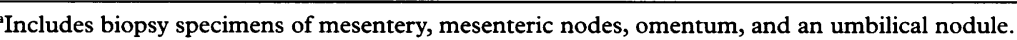

'Includes biopsy specimens of mediastinal nodes, thymic region, and pericardium.

'Includes one mass in cerebellopontine angle.

'Only includes specified ovarian masses. Other examples are likely to be classified under abdominal/pelvic mass. eSoft tissues, distinct from jaws.

Two biopsy specimens from two different sites, submitted from two patients.

sTwo biopsy specimens from two different sites, submitted from two patients. 
Table 3 UKCCSG NHL trials: distribution of diagnoses by age

\begin{tabular}{|c|c|c|c|c|c|}
\hline \multirow[b]{2}{*}{ Diagnosis } & \multicolumn{5}{|c|}{ Age (years) } \\
\hline & $<1$ & $1-5$ & $6-10$ & $11-15$ & $>16$ \\
\hline Burkitt lymphoma $(n=130)$ & - & 38 & 50 & 41 & 1 \\
\hline Lymphoblastic $(n=84)$ & 1 & 34 & 25 & 24 & - \\
\hline Large cell anaplastic $(n=4)$ & - & 9 & 13 & 23 & 1 \\
\hline $\begin{array}{l}\text { Centroblastic } \\
\text { Centroblastic/centrocytic } \\
(\mathrm{n}=10)\end{array}$ & - & 2 & 2 & 6 & - \\
\hline Other B-lineage $(n=14)$ & - & 2 & 6 & 5 & 1 \\
\hline $\begin{array}{l}\text { Peripheral T, Other T-lineage } \\
(n=4)\end{array}$ & - & 2 & 1 & - & 1 \\
\hline Histocytic $(n=1)$ & - & 1 & - & - & - \\
\hline $\begin{array}{l}\text { Non-Hodgkin lymphoma } \\
\text { (NOS) }(n=4)\end{array}$ & - & 1 & 1 & 2 & - \\
\hline $\begin{array}{l}\text { Reactive/no evidence of } \\
\text { lymphoma seen }(n=11)\end{array}$ & - & 3 & 4 & 4 & - \\
\hline No diagnosis made $(n=4)$ & - & 2 & 1 & 1 & - \\
\hline Total & 1 & 94 & 103 & 106 & 4 \\
\hline
\end{tabular}

but also in their immunophenotype. There was also a high level of agreement between the panel diagnoses and those of the referring pathologists. Two referred diagnoses of nonHodgkin lymphoma, single examples of T-nonHodgkin lymphoma NOS and anaplastic large cell lymphoma, were eventually rejected by the panel as non-neoplastic. One referred diagnosis of anaplastic large cell lymphoma was re-classified as Hodgkin disease. No examples of non-lymphomatous, round cell tumours, mis-diagnosed as non-Hodgkin lymphoma, were encountered. The largest area of disagreement would seem to be amongst the Burkitt lymphomas, 35 of which were diagnosed by the referring pathologist as B-lymphoblastic lymphomas (see discussion). Many of the other discrepancies between the submitted and the panel diagnoses were minor and related to the immunophenotype assignment or were of a semantic nature.

\section{Discussion}

This study gave us an unprecedented opportunity to examine and categorise a large series of unselected non-Hodgkin lymphomas in children. It does, however, have a number of limitations. The amount of clinical information available to us was usually small and it was sometimes necessary to obtain more details from the paediatricians. The anatomical sites of disease, listed in table 2, represent the major areas of involvement and also, in children with multifocal disease, the regions which were most accessible for biopsy. The diagnostic material submitted to the panel was usually restricted to 10 paraffin wax sections, with little opportunity to undertake detailed immunophenotypic analysis in difficult cases. When setting up our study in 1990, we selected L26 (CD20) as the best available B-lineage marker at that time. ${ }^{2}$ L26 does, however, have limitations, especially for a study of childhood lymphomas, as it does not stain very early B cells. In contrast, CD79a is expressed on B cells at the time when immunoglobulin is first synthesised. ${ }^{3}$ If we had used this antibody, throughout the study, we should probably have detected more B-lymphoblastic lymphomas which may not express CD20. This problem does not apply to Burkitt lymphoma which represents a later stage of B-cell development at which CD20 is always expressed. Staining for terminal deoxynucleotidyl transferase, which has recently been reported in paraffin wax embedded tissue sections, ${ }^{4}$ would also provide a marker for precursor B- or T-cell lymphomas (lymphoblastic lymphomas).

The only major area of disagreement between the panel diagnosis and that of the referring pathologists was of Burkitt lymphoma which was originally described as B-lymphoblastic lymphoma in 35 cases. This discordance, however, relates more to the use of terminology than to histological interpretation. Burkitt lymphoma was categorised as a B-lymphoblastic lymphoma in the first version of the Kiel classification, ${ }^{5}$ an error that was subsequently rectified in the updated version of this classification. ${ }^{6}$ In the FAB classification of lymphoblastic leukaemia, cases of Burkitt lymphoma with extensive bone marrow involvement and overspill into the peripheral blood are still referred to as acute lymphoblastic lymphoma (ALL-L3). ${ }^{7}$ Lymphoblastic lymphomas arise from early or progenitor B and T cells, whereas Burkitt lymphoma cells show features of more mature B cells in their expression of lineage markers and surface immunoglobulin. The molecular genetics of Burkitt lymphoma and B-lymphoblastic lymphoma are different, as are their immunophenotype and morphology. ${ }^{8}$ There is a need for classification systems to make a clear distinction between these separate diseases.

Burkitt lymphoma is the commonest subtype of childhood non-Hodgkin lymphoma in the UK. By definition, this is categorised as sporadic or non-endemic Burkitt lymphoma. Endemic and non-endemic Burkitt lymphoma are morphologically indistinguishable, ${ }^{9}$ probably because both groups of tumours have translocations between the c-myc gene and one of the immunoglobulin genes, leading to c-myc deregulation. ${ }^{10}$ Deregulated c-myc results in cells that continuously replicate but do not differentiate and, therefore, show little morphological variation. Despite their morphological identity, endemic and sporadic Burkitt lymphoma differ in their molecular genetics, in that the breakpoints in relation to the c-myc and immunoglobulin genes are usually different. $^{11-13}$ In addition, endemic Burkitt lymphoma is always associated with EpsteinBarr virus, whereas only one third of nonendemic cases carry the virus. ${ }^{14}$ The two tumours also differ in their clinico-anatomical features. Endemic Burkitt lymphoma has a sex ratio of 2.1 males to one female, ${ }^{15}$ whereas in this series the ratio was 5.5:1. Non-endemic Burkitt lymphoma presents most frequently with abdominal and pelvic tumours, often involving the ileocaecal region. The oropharynx and nasopharynx are the second most common tumour sites. This anatomical distribution would be uncommon in endemic Burkitt lymphoma in which abdominal tumours are usually retroperitoneal and tumours of Waldeyer's ring are rare. ${ }^{16}$ Peripheral lymphadenopathy is almost never seen in endemic Burkitt lymphoma, whereas it was a presenting 
feature in $10 \%$ of the cases of non-endemic Burkitt lymphoma in this series.

The clinical and anatomical differences between endemic and sporadic Burkitt lymphoma have been recorded previously. ${ }^{17}$ If Burkitt lymphoma had not been defined on the basis of its microscopic features which, as stated above, are probably directly related to c-myc deregulation, the sporadic disease would not have been labelled as Burkitt lymphoma. The semantic confusion surrounding these tumours has been further complicated by the use of the terms "Burkitt-like" or "small non-cleaved cell non-Burkitt". When applied to childhood lymphomas, the distinction between Burkitt and non-Burkitt lymphomas seems to lack clinical importance and may be because of minor morphological variation or histological artefact. ${ }^{18}$ Morphological, phenotypic and clinical differences have emerged when this distinction is applied to lymphomas at all ages, with Burkitt lymphomas predominating in children and Burkitt-like lymphomas in adults. ${ }^{19}{ }^{20}$ These Burkitt-like lymphomas do not show the rearrangements of the c-myc and immunoglobulin genes that characterise Burkitt lymphoma. ${ }^{20}$ It is our opinion that the designation Burkitt-like, as a single diagnostic term, should be avoided and that, at the present time, such cases should be designated high grade B-cell lymphomas, Burkitt-like, as recommended in the REAL classification. ${ }^{8}$ Staining sections with the proliferation marker MIB1 (Ki-67) is used by one of the authors (DHW) as an aid to the identification of Burkitt lymphoma. All Burkitt lymphomas show c-myc deregulation and, thus, have $100 \%$ labelling index of the tumour cells. This level of labelling is rarely seen in other lymphomas.

The majority of the lymphoblastic lymphomas were of the T-cell phenotype. Mediastinal tumours were common in this group and in 27 patients this was the site of biopsy, although, in 21 patients, enlarged cervical or supraclavicular lymph nodes provided a more accessible biopsy site. The use of an antibody directed against CD79a would probably have identified a B-cell lineage for some of the cases of indeterminate phenotype. ${ }^{3}$ Involvement of the skin and soft tissues, which is said to be a characteristic of B- and pre-B-lymphoblastic lymphomas, ${ }^{21-23}$ was seen in $25 \%$ of the B-cell and indeterminate group but in only $5 \%$ of the T-lymphoblastic lymphomas. Although bone marrow infiltration was observed in three cases of lymphoblastic lymphoma, this constituted less than $25 \%$ of the cells at which level the case would have been designated as lymphoblastic leukaemia and not entered into the nonHodgkin lymphoma trial.

Primary anaplastic large cell lymphoma is the third commonest childhood non-Hodgkin lymphoma in this series. These patients were generally older than the children with Burkitt lymphoma and lymphoblastic lymphoma, and most presented with cervical lymphadenopathy. Skin, soft tissues and bone were the presenting sites in seven patients and the mediastinum in three. Pathologists will be aware of the diagnostic pitfalls associated with this neo- plasm. The abundant cytoplasm of the tumour cells, their cohesive growth pattern and tendency to infiltrate the sinuses of lymph nodes may lead to a diagnosis of metastatic tumour, particularly undifferentiated carcinoma or amelanotic melanoma. The frequent expression of $\mathrm{EMA}^{24}{ }^{25}$ by the tumour cells and, in rare instances, cytokeratins, ${ }^{26} 27$ together with the failure of some cases to express CD45 $5^{27}$ or lineage markers, may compound this error. Some cases induce an intense histiocytic reaction that may obscure the tumour cells. ${ }^{29}{ }^{30}$ The entity anaplastic large cell lymphoma, Hodgkin-like, ${ }^{8}$ may be impossible to differentiate from Hodgkin disease, but no such cases occurred in this series. The chromosomal translocation $(2 ; 5)(\mathrm{p} 23 ; \mathrm{q} 35)$ occurs in about $30-40 \%$ of cases of anaplastic large cell lymphoma and seems to be more common in childhood than adult cases. ${ }^{31-34}$ The $(2 ; 5)$ translocation results in the fusion of the nucleophosmin gene on chromosome $5 \mathrm{q} 35$ to a novel tyrosine kinase encoding gene designated anaplastic lymphoma kinase on chromosome $2 \mathrm{p} 23^{35}$ and in the production of an abnormal fusion protein. ${ }^{36}$ The deregulated tyrosine kinase activity of this fusion protein may be important in the pathogenesis of anaplastic large cell lymphoma. Antibodies to this fusion protein have been shown to stain both the nucleus and cytoplasm of tumour cells in about $30 \%$ of cases of anaplastic large cell lymphoma, mainly those occurring in childhood and having a good prognosis. ${ }^{36}$ It seems, therefore, that most cases of anaplastic large cell lymphoma in adults have a different pathogenesis from those occurring in childhood. It is yet to be determined how homogeneous the childhood cases in our series are. Five cases showed $t(2 ; 5)$ by conventional cytogenetics.

Patients with congenital immunodeficiency syndromes are at increased risk of developing non-Hodgkin lymphomas. There were two children with ataxia telangiectasia in this series. One developed high grade non-Hodgkin lymphoma of indeterminate lineage, involving the brain and cervical lymph nodes, at the age of three years. The other patient developed an anaplastic large cell lymphoma of B-phenotype involving an axillary lymph node at the age of 10 .

We are indebted to the many consultant pathologists who We are indebted to the many consultant pathologists who We thank Ms Elizabeth Philp and her staff for technical help and We thank Ms Elizabeth Philp and her staff for technical help and
Julie Foster for typing the manuscript. The latter part of the Julie Foster for typing the manuscript. The latter part of the
work was funded by grants made to the UKCCSG by the work was funded by grar
Department of Health.

1 Sandlund JT, Downing JR, Crist WM. Non-Hodgkin's lymphoma in childhood. $N$ Engl F Med 1996;334:1238-48.

Norton AJ, Isaacson PG. Detailed phenotypic analysis of B-cell lymphoma using a panel of antibodies reactive in B-cell lymphoma using a panel of antibodies reactive in routinely fixed,

3 Mason DY, Cordell JL, Tse AJD, van Dongen JJM, van Noesel CJM, Micklem K, et al. The IgM associated protein Noesel CJM, Micklem $\mathrm{K}$, et al. The IgM associated protein
mb-1 as a marker of normal and neoplastic B-cells. $f$ $\mathrm{mb}-1$ as a marker of norm

4 Orazi A, Cotton J, Cattoretti G, Kotylo PK, John K, Manning JT, Neiman RS. Terminal deoxynucleotidyl transferase staining in acute leukemia and normal bone marrow in routinely processed paraffin sections. $\mathrm{Am} \mathrm{f}$ Clin Pathol 1994;102:640-5.

5 Gerard-Marchant R, Hamblin I, Lennert K, Rilke F, Stansfeld AG, van Unnik JAM. Classification of non-Hodgkin's lymphomas. Lancet 1974;ii:406. 
6 Stansfeld AG, Diebold J, Noel H, Kapanci Y, Rilke F, Kelényi $\mathrm{G}$, et al. Updated Kiel classification for lymphomas. ényi G, et al. Updat
Lancet $1988 ; \mathbf{i}: 292-3$.

7 Bennett JM, Catovsky D, Flandrin G, Galton DAG, Gralnick HR, Sultan C. Proposals for the classification of the acute leukaemias. Br f Haematol 1976;33:451-8.

8 Harris NL, Jaffe ES, Stein H, Banks PM, Chan JKC, Cleary $M L$, et al. A revised European-American classification of lymphoid neoplasms: A proposal from the International Lymphoma Study Group. Blood 1994;84:1361-92.

9 Berard C, O'Conor GT, Thomas LB, Torloni H. Histopathological definition of Burkitt's tumour. Bull World Health Organ 1969;40:601-7.

10 Knowell PC, Croce CM. Chromosome translocations and oncogenes in human lymphoid tumors. Am $\mathcal{F}$ Clin Pathol 1990;94:229-37.

11 Gutierrez M, Bahitia K, Barraga R, Diez B, Sackmann MF, de Andreas M. Molecular epidemiology of Burkitt's lymphoma from South America: Differences in breakpoint locations and EBV association from tumors in other world regions. Blood 1992;79:3261-6.

2 Pilicci P, Knowles D, Magrath I, Dalla-Favera R. Chromosomal breakpoints and structural alterations of the C-MYC locus differ in endemic and sporadic forms of Burkitt lymphoma. Proc Natl Acad Sci USA 1986;83:2984-90.

13 Neri A, Barriga F, Knowles D, Magrath I, Dalla-Favera R. Different regions of the immunoglobulin heavy-chain locus are involved in chromosomal translocations in distinct pathogenetic forms of Burkitt lymphoma. Proc Natl Acad pathogenetic forms of Burk
Sci USA 1988;85:2748-54.

14 Magrath IT. The pathogenesis of Burkitt's lymphoma. In: Van de Woued GF, Klein G, eds. Advances in cancer research. San Diego: Academic Press, 1990:133-270.

15 Burkitt DP. General features and facial tumours. In: Burkitt DP, Wright DH, eds. Burkitt's lymphoma. Edinburgh and London: E and S Livingstone, 1970:6-15.

16 Wright DH. Gross distribution and haematology. In: Burkitt DP, Wright DH, eds. Burkitt's lymphoma. Edinburgh and London: $\mathrm{E}$ and S Livingstone, 1970:64-81.

17 Magrath IT, Sariban E. Clinical features of Burkitt's lymphoma in the USA. In: Lenoir G, O'Conor G, Olweny CLM, eds. Burkitt's lymphoma: A human cancer model. Lyon: IARC Scientific Publications, Number 60, 1985:119-27.

18 Hutchison RE, Murphy SB, Fairclough DL, Shuster JJ, Sullivan MP, Link MP, et al. Diffuse, small, non-cleaved cell lymphoma in children. Burkitt's versus non-Burkitt's types: lymphoma in children. Burkitt's versus non-Burkitt's types:
Results from the Pediatric Oncology Group and St Jude Results from the Pediatric Oncology Group and St
Children's Research Hospital. Cancer 1989;64:23-8.

19 Payne CM, Grogan TM, Cromey DW, Bjore CG, Kerrigan DP. An ultrastructural, morphometric and immunophenotypic evaluation of Burkitt's and Burkitt's-like lymphomas. Lab Invest 1987;57:200-18.

20 Yano T, van Krieken JHJM, Magrath IT, Longo DL, Jaffe ES, Raffeld M. Histogenetic correlations between subcategories of small, non-cleaved cell lymphomas. Blood 1992;79:1282-90.

21 Bernard A, Murphy SB, Melvin S, Bowman P, Caillaud J, Lemerle $\mathrm{J}$, et al. Non- $\mathrm{T}$, non-B lymphomas are rare in childhood and associated with cutaneous tumor. Blood 1982;59:549-54.

22 Link MP, Roper M, Dorfman RF, Crist WM, Cooper MD, Levy R. Cutaneous lymphoblastic lymphoma with pre-B markers. Blood 1983;61:838-41.
23 Cossman J, Chused TM, Fisher RI, Magrath I, Bollum F Jaffe ES. Diversity of immunological phenotypes of Jaffe ES. Diversity of immunological phenotypes of

24 Delsol G, Al Saati T, Gatter KC, Gerdes J, Schwarting RE, Caveriviere $\mathrm{P}$, et al. Co-expression of epithelial membrane antigen (EMA), $\mathrm{Ki}-1$ and interleukin-2 receptor by anaplastic large cell lymphomas. Diagnostic value in so-called malignant histiocytosis. Am $\mathcal{F}$ Pathol 1988;130: 59-70.

25 Fujimoto J, Hata J, Ishii E, Kiyokawa N, Tanaka S, Morikawa Y, et al. Ki-1 lymphoma in childhood: Immunohistochemical analysis and the significance of epithelial mistocherch membrane antigen (EMA

26 Frierson HF, Belafiore FJ, Gaffey MJ, McCary WS, Innes DJ, Williams ME. Cytokeratin in anaplastic large cell lymphoma. Mod Pathol 1994;7:317-21.

27 Gustmann C, Altmannsberger M, Osborn M, Griesser H, Feller AC. Cytokeratin expression and vimentin content in large cell anaplastic lymphomas and other non-Hodgkin's lymphomas. Am f Pathol 1991;138:1413-22.

28 Falini B, Pileri S, Stein H, Dieneman D, Dallenbach F, Delsol $G$, et al. Variable expression of leucocyte common (CD45) antigen in CD30 (Ki-1) positive anaplastic large cell lymphoma: Implications for the differential diagnosis between lymphoid and non-lymphoid malignancies. Hum between lymphoid and
Pathol 1990;21:624-9.

29 Pileri S, Falini B, Delsol G, Stein H, Baglioni P, Poggi S, et al. Lymphohistocytic T-cell lymphoma (anaplastic large cell lymphoma $\mathrm{CD} 30+/ \mathrm{Ki}-1+$ with a high content of reactive histiocytes). Histopathology 1990;16:383-91.

30 Pileri S, Sabattini E, Poggi IS, Amini M, Falini B, Stein H. Lymphohistiocytic T-cell lymphoma [letter]. Histopathology 1994;25: 191-3.

31 Rimokh R, Magaud J-P, Berger F, Samarut J, Coiffier B, Germain $\mathrm{D}$, et al. A translocation involving a specific
breakpoint (q35) on chromosome 5 is characteristic of breakpoint (q35) on chromosome 5 is characteristic of
anaplastic large cell lymphoma ("Ki-1 lymphoma"). $B r 7$ anaplastic large cell lympho

32 Le Beau MM, Bitter MA, Larson RA, Doane LA, Ellis ED, Franklin WA, et al. The $\mathrm{t}(2 ; 5)(\mathrm{p} 23 ; \mathrm{q} 35)$ : Recurring chromosomal abnormality in $\mathrm{Ki}-1$ positive anaplastic large cell lymphoma. Leukemia 1989;3:866-70.

33 Bitter MA, Franklin WA, Larson RA, McKeithan TW, Rubin CM, Le Beau MM, et al. Morphology in $\mathrm{Ki}-1$ (CD30)-positive non-Hodgkin's lymphoma is correlated with clinical features in the presence of a unique chromosomal abnormality, $\mathrm{t}(2 ; 5)(\mathrm{p} 23 ; \mathrm{q} 35)$. Am f Surg Pathol 1990;14:305-16.

34 Mason DY, Bastard C, Rimokh R, Dastugue N, Huret J-L, Kristoffersson U, et al. CD30-positive large cell lymphomas ("Ki-1 lymphoma") are associated with a chromosomal translocation involving 5q35. Br f Haematol 1990;74:1618 .

35 Morris SW, Kirstein MN, Valentine MB, Dittmer KG, Shapiro DN, Saltman DL, Look AT. Fusion of a kinase gene (ALK), to a nucleolar protein gene, NPM, in nonHodgkin's lymphoma. Science 1994;263:1281-6.

36 Shiota $M$, Nakamura S, Ichinohasama R, Abe $M$, Akagi T, Takeshita $M$, et al. Anaplastic large cell lymphomas expressing the novel chimeric protein p80 $\mathrm{NPM}$ AL.K: A distinct clinico-pathologic entity. Blood 1995;86: 1954-60 